Biodiversity

\title{
Have we so far only seen the tip of the iceberg? Exploring species diversity and distribution of the giant amphipod Eurythenes
}

\section{Charlotte Havermans}

To cite this article: Charlotte Havermans (2016): Have we so far only seen the tip of the iceberg? Exploring species diversity and distribution of the giant amphipod Eurythenes, Biodiversity, DOI: 10.1080/14888386.2016.1172257

To link to this article: http://dx.doi.org/10.1080/14888386.2016.1172257

曲 Published online: 29 Apr 2016.

Submit your article to this journal $\pi$

Q View related articles $\asymp$

View Crossmark data $־$ 


\title{
Have we so far only seen the tip of the iceberg? Exploring species diversity and distribution of the giant amphipod Eurythenes
}

\author{
Charlotte Havermans $s^{a, b, c}$ \\ ${ }^{a}$ OD Nature, Royal Belgian Institute of Natural Sciences, Brussels, Belgium; 'barine Zoology, BreMarE - Bremen Marine Ecology, University \\ of Bremen, Bremen, Germany; 'Functional Ecology, Alfred Wegener Institute Helmholtz Centre for Polar and Marine Research, Bremerhaven, \\ Germany
}

\begin{abstract}
Additional material of the iconic giant amphipod Eurythenes was investigated. Recently, the species $E$. gryllus has been separated into 12 distinct species-level lineages of which several have been described as distinct species, based on both morphology and genetics. This study revealed three additional species-level lineages from unique sampling localities, showing that with minimal sampling effort, species diversity within Eurythenes can still increase. One species-level lineage was found in the Indian Ocean and another one in the Pacific, which was subsequently identified as $E$. thurstoni. In addition to the three species already reported from the Southern Ocean (E. maldoror, E. gryllus s.s. and E. andhakarae), a supplementary bathyal species was found in the Weddell Sea. $E$. gryllus was confirmed to be amphitropical including newly sampled localities around the Kerguelen Islands and additional samples from the Svalbard Archipelago. Building on new and earlier data, geographic and bathymetric distributions of the different species that have been discovered so far are presented here and several factors are evaluated for their likelihood of having triggered past speciation events in this scavenger. Topographic and hydrographical features are discussed but rejected as sufficient reasons for the distributional patterns observed. Bathymetric segregation is interpreted with regard to what is known about the ecology of the species. The previously reported genetic break around $3000 \mathrm{~m}$ persists in this new data-set for all species but one. This study underlines the need of processing all individuals sampled, since two or more sympatric species are found in different proportions, and that conclusions regarding diversity and distribution may drastically change when increasing sampling intensity and coverage. Finally, I suggest here that only a mere fraction of all Eurythenes species has yet been discovered and that a more complete knowledge of the ecology of the species is of paramount importance for interpreting their evolution.
\end{abstract}

ARTICLE HISTORY

Received 17 February 2016 Accepted 26 March 2016

\section{KEYWORDS}

Lysianassoidea; deep

sea; genetic diversity; DNA barcoding; species complex, COI sequences, phylogeography, bathymetric gradient, speciation

\section{Introduction}

The giant lysianassoid amphipod Eurythenes gryllus (Lichtenstein in Mandt, 1822) is one of the icons of the deep-sea fauna, owing to its large size and conspicuous colour, high abundances and rapid appearance at baited traps. It has been extensively sampled and various aspects, e.g. basic life history characteristics (Baldwin and Smith 1987; Thurston and Bett 1995), metabolism (Premke and Graeve 2009), feeding strategy (Hargrave 1985; Hargrave et al. 1995), pigments (Thoen, Johnsen, and Berge 2011) and vertical distribution (e.g. Ingram and Hessler 1983), investigated. However, none of these studies tackled the question of whether the investigated specimens belonged to the same species occurring throughout the world's deep ocean. Despite the studies of France and Kocher (1996a,b) two decades ago, which raised suspicion about the cosmopolitan nature of its distribution, the genetic connectivity of E. gryllus has only recently been addressed with large-scale sampling and modern molecular methods. An integrative study based on detailed morphological examinations and various molecular species-delimitation methods confirmed that E. gryllus represents a species complex (Havermans et al. 2013). The previously overlooked Eurythenes species clearly differ in their genes, morphology and distribution patterns, the latter being geographically partly overlapping but clearly separated on the bathymetric scale. A genetic break was observed around $3000 \mathrm{~m}$, since there was no lineage that comprised both specimens sampled below and above this depth. So far, based on morphological and molecular analyses, 
five different species have been (re-)described based on a reverse-taxonomy approach (Markmann and Tautz 2005): E. andhakarae d'Udekem d'Acoz and Havermans 2015; E. maldoror d'Udekem d'Acoz and Havermans 2015; E. sigmiferus d'Udekem d'Acoz and Havermans 2015; E. magellanicus (H. Milne Edwards 1848) and E. gryllus (Lichtenstein in Mandt, 1822) s.s. (d'Udekem d'Acoz and Havermans 2015). A more extensive data-set of $16 \mathrm{~S}$ rDNA sequences, complemented with sequences from previous studies, unveiled another four supplementary species-level lineages, which could not be investigated morphologically. In the Southern Ocean alone, three distinct Eurythenes species were found, with the two abyssal ones (sampled at depths below $3000 \mathrm{~m}$ ) occurring in sympatry and the bathyal species (from depths above $3000 \mathrm{~m}$ ) representing a bipolar species (Havermans et al. 2013). The study by Ritchie, Jamieson, and Piertney (2015) revealed four more species-level lineages of Eurythenes in a single trench, i.e. the Peru-Chile Trench: one hadal, two abyssal occurring in sympatry, and one bathyal lineage. One of the abyssal ones corresponded genetically to E. magellanicus, extending its distribution previously limited to the Southwest Atlantic to the Southeast Pacific Ocean, but apparently occurring only at abyssal depths. However, a specimen from the Peru-Chile Trench identified as E. magellanicus was illustrated by Eustace et al. (2016). If at all corresponding to any of the described species based on its morphology, it would rather be E. sigmiferus due to the crested pleonites, instead of magellanicus from which it is visibly distinct. Crested individuals have also been reported from other localities such as the Mid-Atlantic Ridge and the Indian Ocean at abyssal depths (for an exhaustive list see d'Udekem d'Acoz and Havermans 2015) - whether these and the abyssal ones represent the same species needs to be further verified.

The genus Eurythenes was, until recently, considered to be composed of only three species: E. gryllus, E. obesus (Chevreux 1905) and E. thurstoni (Stoddart and Lowry 2004) but with the aforementioned studies, it now exceeds a dozen. All species but $E$. obesus have been found in baited traps on the seafloor, and hence are at least facultative scavengers. E. obesus has never been found in baited traps but has been sampled with midwater trawls, but very little is known about its ecology. Its feeding regime covers a wide array of prey: from soft-bodied zooplankton (e.g. pelagic cnidarians and tunicates) to sponges as well as predation on pelagic fish (d'Udekem d'Acoz and Havermans 2015). E. thurstoni often enters baited traps but is also frequently caught in midwater trawls (Stoddart and Lowry 2004) and hence, a more pelagic lifestyle has been attributed to this species. Eurythenes species previously identified as E. gryllus are believed to be rather benthopelagic since the majority has been caught by means of baited traps, and more mature stages including ovigerous females migrate far above the seafloor, where they have been caught with midwater traps or trawls (e.g. Charmasson and Calmet 1987; Smith et al. 1979). A summary of the current knowledge on the biology of the different species can be found in d'Udekem d'Acoz and Havermans (2015). Nonetheless, despite the significant research effort dating as far back as the seventies, the ecology and life history of these giant amphipods remain elusive: questions related to their distribution between the seafloor and the sea surface, their feeding habits when not feeding on artificial food falls and their social structure are yet unsolved. Moreover, due to the taxonomic splitting initiated with molecular evidence, studies on the biology of 'E. gryllus' should actually be scattered across the complex of species which will now render generalisations of their results more difficult.

With an aim to increase sampling intensity and coverage for a better understanding of the distributional ranges of Eurythenes species and the factors determining them, I examined here additional specimens from museum collections, from previously studied material and from new samples gathered during recent expeditions. This material for molecular analyses originates from several high-Antarctic and sub-Antarctic localities in the Southern Ocean, localities in the northern and southern Pacific Ocean and the previously unsampled Indian Ocean. Building on new and earlier data, a review of the different species that have been discovered so far is presented and different factors are evaluated for their likelihood of having triggered past speciation events in this giant scavenging amphipod.

\section{Material and methods}

Material identified as E. gryllus or Eurythenes spp. was obtained from museum or institute collections and was previously sampled during expeditions of RV Jan Mayen, RV Polarstern, RV Vizconde de Eza and RV Coriolis, using baited traps or trawls. Sampling details are listed in Table 1. The newly obtained material originated from depths ranging from $750 \mathrm{~m}$ to $4625 \mathrm{~m}$ covering both the bathyal $(<3000 \mathrm{~m})$ and abyssal $(>3000 \mathrm{~m})$ zone and included geographic localities off Taiwan, Samoa, in the Mozambique Channel, in the Weddell Sea and along the Kerguelen Islands and the Svalbard archipelago.

Genomic DNA was isolated from pereopod 6 using the Nucleospin Tissue kit" (Macherey-Nagel) according to the manufacturer's protocol. Polymerase chain reaction (PCR) amplifications of a fragment of the mitochondrial cytochrome oxidase subunit 1 (COI) gene were carried out using the LCO1490 and HCO2198 primers (Folmer et al. 1994). Since some of the material was old (the specimens from Samoa were collected in 1977) and/or preserved in diluted ethanol, only the COI gene fragment 
Table 1. Data on Eurythenes specimens sampled for this study: locality, geographic coordinates, depth (m), supplementary information on sampling and collection numbers, as well as GenBank accession numbers. Abbreviations: n.d. - no data, BT - baited traps.

\begin{tabular}{|c|c|c|c|c|c|c|}
\hline Abbreviation & Code & Locality & Coordinates & Depth & Suppl. information & $\begin{array}{l}\text { Acc } \\
\text { Number }\end{array}$ \\
\hline Arctic-c8 & EgrC182 & Svalbard & $82^{\circ} 16^{\prime} \mathrm{N} 20^{\circ} 52^{\prime} \mathrm{E}$ & 1660 & RV Jan Mayen TSZCr13640 & KX078265 \\
\hline Arctic-c9 & EgrC183 & Svalbard & $82^{\circ} 16^{\prime} \mathrm{N} 20^{\circ} 52^{\prime} \mathrm{E}$ & 1660 & RV Jan Mayen TSZCr13640 & KX078264 \\
\hline Arctic-c10 & EgrC184 & Svalbard & $82^{\circ} 16^{\prime} \mathrm{N} 20^{\circ} 52^{\prime} \mathrm{E}$ & 1660 & RV Jan Mayen TSZCr13640 & KX078263 \\
\hline Arctic-c11 & EgrC185 & Svalbard & $82^{\circ} 16^{\prime} \mathrm{N} 20^{\circ} 52^{\prime} \mathrm{E}$ & 1660 & RV Jan Mayen TSZCr13640 & KX078262 \\
\hline Arctic-c12 & EgrC186 & Svalbard & $82^{\circ} 16^{\prime} \mathrm{N} 20^{\circ} 52^{\prime} \mathrm{E}$ & 1660 & RV Jan Mayen TSZCr13640 & KX078261 \\
\hline WDL-a4 & EgrC169 & Weddell Sea & $67^{\circ} 30^{\prime} \mathrm{S} 00^{\circ} 00^{\prime} \mathrm{W}$ & 4625 & RV Polarstern ANDEEP III 59BT & KX078270 \\
\hline WDL-a5 & EgrC170 & Weddell Sea & $67^{\circ} 30^{\prime} \mathrm{S} 00^{\circ} 00^{\prime} \mathrm{W}$ & 4625 & RV Polarstern ANDEEP III 59BT & KX078269 \\
\hline WDL-a6 & EgrC171 & Weddell Sea & $67^{\circ} 30^{\prime} \mathrm{S} 00^{\circ} 00^{\prime} \mathrm{W}$ & 4625 & RV Polarstern ANDEEP III 59BT & KX078268 \\
\hline WDL-a7 & EgrC172 & Weddell Sea & $67^{\circ} 30^{\prime} \mathrm{S} 00^{\circ} 00^{\prime} \mathrm{W}$ & 4625 & RV Polarstern ANDEEP III 59BT & KX078267 \\
\hline WDL-a8 & EgrC173 & Weddell Sea & $67^{\circ} 30^{\prime} \mathrm{S} 00^{\circ} 00^{\prime} \mathrm{W}$ & 4625 & RV Polarstern ANDEEP III 59BT & KX078266 \\
\hline WDL-a9 & EgrC174 & Weddell Sea & $67^{\circ} 30^{\prime} \mathrm{S} 00^{\circ} 00^{\prime} \mathrm{W}$ & 4625 & RV Polarstern ANDEEP III 59BT & KX078260 \\
\hline WDL-a10 & EgrC175 & Weddell Sea & $67^{\circ} 30^{\prime} \mathrm{S} 00^{\circ} 00^{\prime} \mathrm{W}$ & 4625 & RV Polarstern ANDEEP III 59BT & KX078259 \\
\hline WDL-a11 & EgrC176 & Weddell Sea & $67^{\circ} 30^{\prime} \mathrm{S} 00^{\circ} 00^{\prime} \mathrm{W}$ & 4625 & RV Polarstern ANDEEP III 59BT & KX078258 \\
\hline WDL-a12 & EgrC177 & Weddell Sea & $67^{\circ} 30^{\prime} \mathrm{S} 00^{\circ} 00^{\prime} \mathrm{W}$ & 4625 & RV Polarstern ANDEEP III 59BT & KX078257 \\
\hline WDL-a13 & EgrC178 & Weddell Sea & $67^{\circ} 30^{\prime} \mathrm{S} 00^{\circ} 00^{\prime} \mathrm{W}$ & 4625 & RV Polarstern ANDEEP III 59BT & KX078256 \\
\hline WDL-a14 & EgrC179 & Weddell Sea & $67^{\circ} 30^{\prime} \mathrm{S} 00^{\circ} 00^{\prime} \mathrm{W}$ & 4625 & RV Polarstern ANDEEP III 59BT & KX078255 \\
\hline WDL-d1 & EgrC099 & Weddell Sea & n.d. & $<1200$ & RV Polarstern EASIZ II Trap & KX078273 \\
\hline KERG-a1 & EspC201 & Kerguelen Isl. & $50^{\circ} 14^{\prime} \mathrm{S} 65^{\circ} 25^{\prime} \mathrm{E}$ & 1476 & ALCP377.4 & KX078254 \\
\hline KERG-a2 & EspC202 & Kerguelen Is|. & $50^{\circ} 14^{\prime} \mathrm{S} 65^{\circ} 25^{\prime} \mathrm{E}$ & 1476 & ALCP377.4 & KX078253 \\
\hline KERG-a3 & EspC203 & Kerguelen Isl. & $50^{\circ} 14^{\prime} \mathrm{S} 65^{\circ} 25^{\prime} \mathrm{E}$ & 1476 & ALCP377.4 & KX078252 \\
\hline KERG-a4 & EspC204 & Kerguelen IsI. & $50^{\circ} 14^{\prime} \mathrm{S} 65^{\circ} 25^{\prime} \mathrm{E}$ & 1476 & ALCP377.4 & KX078251 \\
\hline KERG-a5 & EspC205 & Kerguelen Is|. & $50^{\circ} 14^{\prime} \mathrm{S} 65^{\circ} 25^{\prime} \mathrm{E}$ & 1476 & ALCP377.4 & KX078250 \\
\hline KERG-b1 & EspC206 & Kerguelen Isl. & $48^{\circ} 29^{\prime} \mathrm{S} 65^{\circ} 09^{\prime} \mathrm{E}$ & 1732 & ALCP 324.08 & KX078249 \\
\hline MOZ-1 & EspC194 & Mozambique Channel & $21^{\circ} 38^{\prime} \mathrm{S} 36^{\circ} 07^{\prime} \mathrm{E}$ & 1161 & RV Vizconde de Eza MAINBAZA CP3146 MNHN-IU-2009-2501 & KX078271 \\
\hline SAM-1 & EspC197 & Apolima Strait, Samoa & n.d. & 750 & RV Coriolis, SAMOA-I, 20.11.1977 MNHN-IU-2009-2512 & KX078272 \\
\hline TAl-1 & EspC226 & Off Taiwan & $22^{\circ} 22^{\prime} \mathrm{N} 119^{\circ} 48^{\prime} \mathrm{E}$ & 1342 & Sta C22T2 & KX078274 \\
\hline
\end{tabular}

could be successfully amplified and sequenced and sometimes only for one specimen per locality. The $25 \mu \mathrm{l}$ PCR reactions consisted of $0.02 \mathrm{U} / \mu \mathrm{l}$ Hotmaster Taq (5Prime $\mathrm{GmbH}$ ), $0.2 \mathrm{mM}$ dNTPs, $0.5 \mu \mathrm{M}$ of forward and reverse primers, 1x PCR-buffer and $1 \mu \mathrm{l}$ (about $30 \mathrm{ng}$ ) of template DNA. PCR conditions were: initial denaturation at $94{ }^{\circ} \mathrm{C}$ for $2 \mathrm{~min}$, followed by 36 cycles of $94^{\circ} \mathrm{C}$ for $20 \mathrm{~s}$, annealing at $42{ }^{\circ} \mathrm{C}$ for $20 \mathrm{~s}$, extension at $65^{\circ} \mathrm{C}$ for $1 \mathrm{~min}$ and a final extension at $65^{\circ} \mathrm{C}$ for $15 \mathrm{~min}$. Amplified products were purified using the Exo-SAP-IT kit (Affymetrix, Santa Clara, Canada). Both forward and reverse strands of the gene were sequenced on an ABI 3130xl sequencer after cycle sequencing with the BigDye Terminator Kit ${ }^{\circ}$ (Applied Biosystems, Foster City, Canada). Sequences were checked for ambiguities and aligned using the software CodonCode Aligner v.3.7.1.1'. (CodonCode Corporation, Deham, MA, USA). In order to prevent inclusion of pseudogenes in the analyses, electropherograms were checked for ambiguous base calls and sequences were translated into amino acids and checked for stop codons. The COI data-set was composed of 44 sequences generated by Havermans et al. (2013) and 26 sequences from newly provided specimens for this study (Table 1), which have been deposited in GenBank (KX078249-KX078274). A first Bayesian analysis was carried out based on 70 COI sequences of E. gryllus sensu lato, two sequences of E. obesus (from d'Udekem d'Acoz and Havermans 2015) and one sequence of Abyssorchomene chevreuxi (Acc. No. GU109229) as outgroup, using MrBayes 3.1.2. (Ronquist and Huelsenbeck 2003). The best-fit substitution model was selected using jModeltest 0.1.1. (Posada 2008) based on the Bayesian Information Criterion (BIC, Schwarz 1978). TPM1+I+G was selected for position 1, F81 for position 2 and TPM $3+\mathrm{G}$ for position 3. Two parallel runs with four chains each were run for 10 million generations; every 1000th generation was sampled, resulting in 10,000 trees. Convergence of runs was monitored using Tracer v1.5 and the first $50 \%$ of the trees were discarded as burn-in, while the last 5000 trees were used to reconstruct the consensus tree and estimate Bayesian posterior probabilities. Relationships between COI haplotypes and their geographic distribution were investigated by generating haplotype networks using TCS 1.21 (Clement, Posada, and Crandall 2000), with gaps considered as a fifth state and a $95 \%$ probability threshold. Finally, a second Bayesian analysis was carried out with the same parameters on the aforementioned data-set now also including the five COI sequences available for Eurythenes from Ritchie, Jamieson, and Piertney (2015) (Acc. Nos. KP713954-KP713958), in order to verify whether the new specimens investigated for this study belong to one of the species-level lineages recently discovered in the Peru-Chile Trench. MrEnt (Zuccon and Zuccon 2014) has been used for the graphical representation of the tree and network analysis. Genetic divergences were compared within and between the different clades using the Kimura two-parameter (K2P) distance model (Kimura 1980), with MEGA version 6 (Tamura et al. 2013). Finally, all distributional data from 
species and lineages, confirmed to be genetically homogeneous, were illustrated on a map and plotted according to their bathymetric records.

\section{Results}

The COI data-set used for the first Bayesian analysis and for the haplotype network analysis comprised 73 sequences (of which 30 unique) consisting of 658 bases, 192 of which were parsimony-informative. The second data-set comprised 78 (34 unique) sequences of 658 bases, of which 200 were parsimony-informative. Translation revealed a higher mutation rate at third codon positions as well as the absence of stop codons, typical for a functional protein-coding gene as opposed to a pseudogene.

For the first Bayesian analysis, similar clades were recovered as in previous molecular analyses (Havermans et al. 2013; d'Udekem d'Acoz and Havermans 2015) based on the COI gene and the results of the statistical parsimony network analysis showed identical unconnected networks Eg1-5 (Figure 1). Three additional lineages were identified: (1) SAM-1 representing a specimen sampled at bathyal depth off Samoa, (2) MOZ-1 representing a specimen from bathyal depth in the Mozambique Channel and (3) WDL-d from bathyal depth in the Weddell Sea. Each of these highly divergent lineages (Figure 1) consisted of only one sequence, and corresponded to a separate unconnected singleton in the network analysis. The divergences between these three lineages, as well as between each of them and the described species of Eurythenes are much higher than previously observed interspecific divergences. Indeed, the smallest genetic distance by which the MOZ1, the WLD-d and the SAM-1 sequences were separated from known Eurythenes species were 22.9, 25 and 23.6\%, respectively (Table 2). Upon a detailed morphological examination, the specimen sampled in the Apolima Strait, off Samoa (South Pacific), corresponded to the description of E. thurstoni. France and Kocher (1996a) published a 16S sequence of $E$. thurstoni but since both sequences cannot be compared I decided to refer to the SAM-1 specimen as E. cf. thurstoni, until evidence of genetic homogeneity can confirm their status as a single species.

Additional specimens sampled around Svalbard (Arctic-c), as well as newly sampled specimens from the Kerguelen Islands were recovered in the tree and network described as E. gryllus sensu stricto (Eg1) (Figure 1). The Kerguelen specimens represented three haplotypes that were scattered across the network and one of them was connected, by a few mutational steps, with the most common haplotype observed for the specimens originating from the Arctic region. The 11 additional sequences from specimens sampled at abyssal depths in the Weddell Sea (locality WDL-a) were recovered in two distinct clades and networks, one corresponding to E. andhakarae (Eg2; 5 sequences) and one to $E$. maldoror (Eg3; 6 sequences). COI haplotypes were shared between the Antarctic Peninsula and Weddell Sea both for E. andhakarae as well as for $E$. maldoror, whereas for the latter species, the most abundant haplotype was shared between the Argentine Abyssal Basin and these localities. The single, small-sized $( \pm 4 \mathrm{~cm})$ specimen sampled at bathyal depth in the Weddell Sea was recovered as a highly divergent lineage, clearly separated from all other specimens sampled in the Southern Ocean. Unfortunately, precise information on depth and coordinates was lost; however, it was known that the specimen was sampled with traps during the expedition EASIZ at a site situated in the eastern Weddell Sea (De Broyer, Rauschert, and Scailteur 1999). Trap sampling was only carried out between 200 and $1450 \mathrm{~m}$ so the specimen is definitely a bathyal one. Hence, four species-level lineages of E. gryllus sensu lato, of which two are bathyal and two abyssal, are now found to occur within the Southern Ocean, several of which are in sympatry.

For specimens belonging to the clade representing the re-described species E. magellanicus, three unconnected networks were recovered: Eg4, Eg5 as in Havermans et al. (2013) and a third one (singleton), representing the sequence (TAI-1) from the specimen sampled at bathyal depth off Taiwan. This sequence was recovered in the Bayesian tree as embedded in the E. magellanicus clade. Finally, one unique haplotype was recovered for the two specimens of E. obesus, forming a distinct clade in the tree.

The second analysis included data from specimens sampled in the Peru-Chile Trench at bathyal, abyssal and hadal depths by Ritchie, Jamieson, and Piertney (2015) and aimed to elucidate whether any of these sequences would be recovered in a clade representing a known or newly detected Eurythenes species. Previously, the authors demonstrated, with various species-delimitation methods, the presence of four distinct species-level lineages along the Peru-Chile Trench, of which three were distinct from the nine other lineages so far uncovered based on $16 \mathrm{~S}$ rDNA divergences by Havermans et al. (2013). According to their results, a fourth group comprising several abyssal specimens (Abyssal-minor) was recovered within the clade composed of E. magellanicus sequences. However, this could not be verified here since no COI sequences were available. The results of the Bayesian analysis (Figure 2) confirm the findings of Ritchie, Jamieson, and Piertney (2015) that the specimens from abyssal depth (Abyssal-major) and those from the hadal group (Hadal) form distinct clades. However, the sequence of the specimen sampled at shallower depth (Bathyal) clustered here together with E. obesus and was only separated from these sequences by a genetic K2P distance of $1.4 \%$ (Table 2). Since E. obesus is easily distinguished from the 


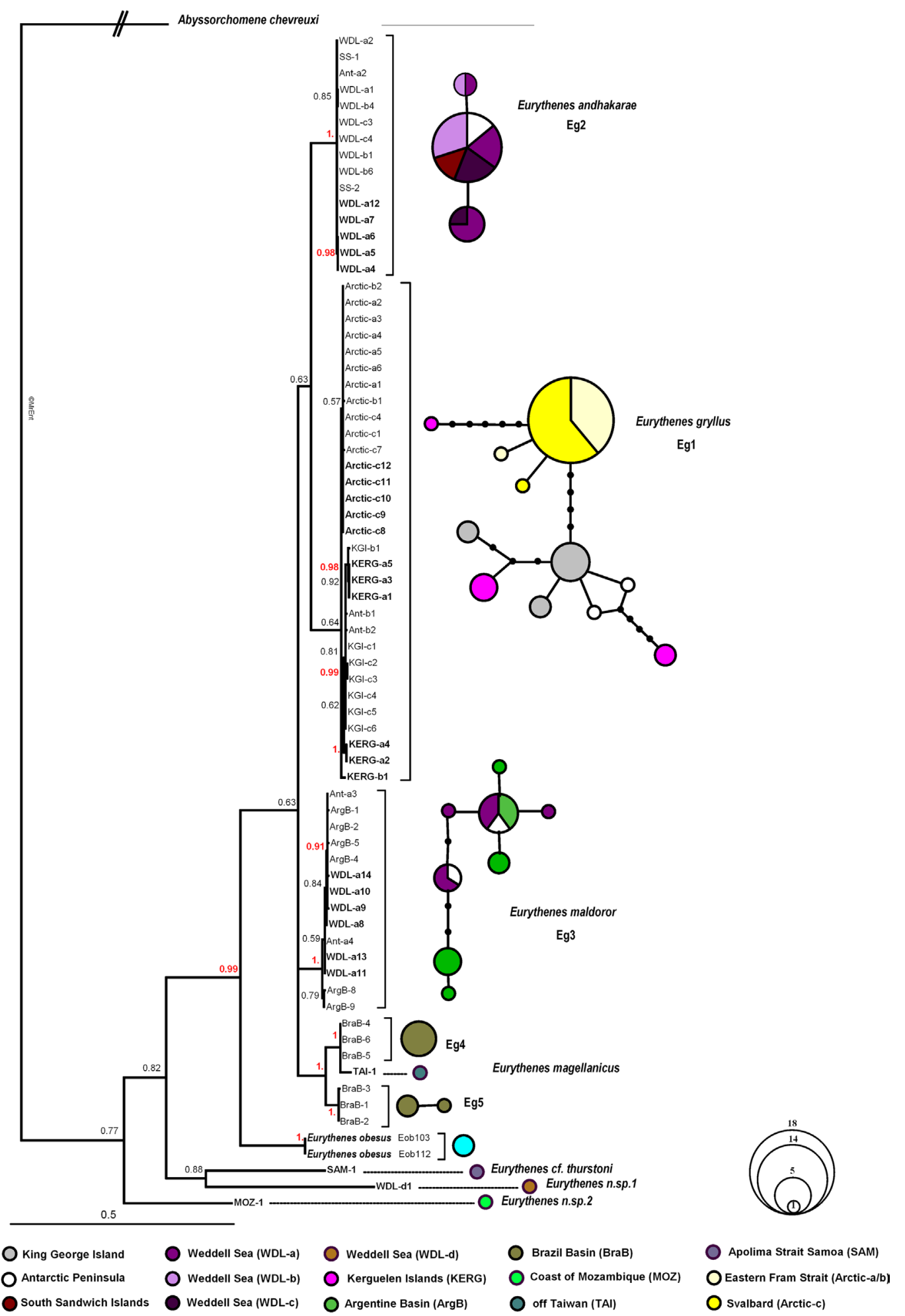

Figure 1. Bayesian tree inferred for the first COI data-set including previously described species (d'Udekem d'Acoz and Havermans 2015) and the newly obtained sequences in this study. Posterior probabilities above 0.50 are shown with values $>0.95$ indicated in red. Results of the statistical parsimony network analysis ( $95 \%$ probability threshold) based on the COI data-set are represented next to the tree. Colours refer to the different sampling localities and the area of each circle is proportionate to the frequency of the haplotype in our sampling (a scale is presented at the right). Black nodes represent hypothetical haplotypes and each line a single substitution. Unconnected networks representing the different clades found in Havermans et al. (2013) are indicated with Eg1-5. Five additional unconnected networks/singletons were found, of which one for the sequenceTAI-1, embedded in the clade representing $E$. magellanicus, all others represent distinct species (E. obesus, E. cf. thurstoni, E. n. sp. 1 and E. n. sp. 2). 
Table 2. Range and mean of pairwise K2P intra- and interclade distances for each clade or species identified with the COI data-set of Eurythenes sequences from d'Udekem d'Acoz and Havermans (2015), Ritchie, Jamieson, and Piertney (2015) as well as this study. The highest intraspecific value and the lowest interspecific value observed are indicated in bold, highlighting the presence of a barcoding gap between them.

\begin{tabular}{lcccc}
\hline & \multicolumn{2}{c}{ Intraclade divergences } & \multicolumn{2}{c}{ Interclade divergences } \\
\cline { 2 - 4 } & Min. - Max. & Mean & Min. - Max. & Mean \\
\hline E. gryllus & & & & \\
E. andhakarae & $0.0-0.022$ & 0.008 & $0.085-0.281$ & 0.121 \\
E. maldoror & $0.0-0.003$ & 0.001 & $0.085-0.283$ & 0.113 \\
E. magellanicus & $0.0-0.013$ & 0.005 & $0.094-0.299$ & 0.117 \\
E. obesus & $0.0-0.064$ & 0.033 & $0.094-0.305$ & 0.122 \\
E. cf. thurstoni (SAM-1) & $0.0-0.014$ & $/$ & $0.142-0.279$ & 0.181 \\
E. n. sp. 1 (WDL-d) & $/$ & $/$ & $0.236-0.292$ & 0.267 \\
E.n. sp. 2 (MOZ-1) & $/$ & $/$ & $0.250-0.305$ & 0.276 \\
E. Hadal & 0.002 & $/$ & $0.158-0.288$ & 0.257 \\
E. Abyssal-major & 0.002 & $0.111-0.276$ & 0.175 \\
\hline
\end{tabular}

other Eurythenes species by its morphology (e.g. narrow linear eyes and extremely long dactyls), species identity should be verified for these bathyal specimens. E. obesus is presumably cosmopolitan; here a genetic homogeneity between the southeast Pacific and localities in the Atlantic sector of the Southern Ocean (near South Georgia, Eob112 and around the Polar Frontal Zone in the mid-Atlantic sector, Eob103) could be observed. This is the first record of $E$. obesus being caught with a baited trap. To summarise, two lineages have been found so far only in the Peru-Chile Trench, whilst the two others extend the distribution of previously described species. With these and the findings of Ritchie, Jamieson, and Piertney (2015), E. magellanicus is now no longer confined to the southwest Atlantic, but also distributed in the North and South Pacific (TAI-1 and A-Minor). The two other groups (Abyssal-major and Hadal) might be endemic to the Peru-Chile Trench.

\section{Discussion}

\section{An up-to-date overview of the distributional ranges of Eurythenes}

The geographic ranges of the different Eurythenes species and their bathymetric recordings are illustrated in Figure 3 and 4, respectively. Concerning the geographic ranges, different patterns are observed. The species $E$. maldoror, E. gryllus, E. magellanicus, E. sigmiferus and the lineage Eg8 are characterised by distributions that span several oceanic basins, whilst $E$. andhakarae has only been found in a single basin, i.e. throughout the Southern Ocean at several distinct localities (e.g. off the Antarctic Peninsula and in the eastern Weddell Sea). Other lineages have so far only been reported from single localities, such as the two lineages discovered on the seamount Horizon Guyot (Eg7, Eg9), the hadal and abyssal lineages each found at a distinct locality along the Peru-Chile Trench, as well as the newly uncovered lineages E. n. sp. 1 and E. n. sp. 2, found in the eastern Weddell Sea and the Mozambique Channel, respectively. The specimen identified as E. cf. thurstoni found off Samoa would, if genetically homogeneous, have been found within the currently known distribution of $E$. thurstoni, encompassing the south Pacific and Atlantic oceans. A previous record of E. thurstoni, used in the molecular analysis of France and Kocher (1996a), was situated around the Bahamas. Despite the geographically extended sampling effort, E. gryllus has not been reported yet from localities outside the Southern and Arctic oceans. The fact that the three haplotypes from the Kerguelen Islands were spread over the network and one of them was connected, although by a few mutational steps, with the most common haplotype in the Arctic region, confirms the validity of the bipolar - or rather amphitropical - E. gryllus s.s., representing a single species distributed in both (sub-)polar regions, with its distribution now also including the sub-Antarctic waters. However, the presence of populations in other oceans cannot be ruled out because of the clear patchiness with both more abundant and rare species observed in a particular site, which is further discussed in a next section. The distribution of $E$. maldoror in the Southern Ocean, previously only found in the Argentine abyssal basin and around the Antarctic Peninsula, now also comprises the eastern Weddell Sea; hence, distributions of the two abyssal species $E$. andhakarae and E. maldoror are now characterised by a substantial overlap. Finally, five cases of true sympatry, representing specimens caught in the same traps, could be observed: (1) the lineage Abyssal-major and E. magellanicus off Ecuador in the Peru-Chile Trench, (2) the species E. sigmiferus and E. magellanicus in the Brazil Abyssal Basin, (3) the lineage Eg7 and E. maldoror on the Horizon Guyot seamount in the North Pacific and $(4,5)$ E. andhakarae and E. maldoror in the 


\section{Eurythenes maldoror} WDL-a9 WDL-a8 Ant-a4 0.8 ArgB-8

WDL-013

WDL-a13 1.00
Eurythenes andhakarae

Abyssorchomene chevreuxi $\left.1.00\right|_{\text {BraB-6 }} ^{\text {BraB-4 }}$ 1.00

BraB-5

LAl-1

Eurythenes magellanicus

\section{$0.98 \mathrm{~W}_{\text {BraB-1 }}^{\text {BraB-3 }}$}

BraB-2

$\left.{ }_{001}^{A m a-K P 713957} \begin{array}{c}\text { AMa-KP713958 }\end{array}\right]$ Eurythenes Abyssal major Peru-Chile Trench $4602 \mathrm{~m}$

0.89 - 103

$\left.\begin{array}{c}0.89 \\ 1.00 \\ \text { Eob1112 } \\ \text { E-KP713954 }\end{array}\right]$

Eurythenes Abyssal major Peru-Chile Trench $4602 \mathrm{~m}$

$100 \mathrm{H}-\mathrm{KP} 713955$

Eurythenes obesus incl. Bathyal Peru-Chile Trench 915 m

H-KP713956

Eurythenes Hadal Peru-Chile Trench 7050 m

Arctic-b2

Arctic-a2

Arctic-a3

Arctic-a4

Arctic-a5

Arctic-a6

0. KGl-b1

KERG-a5

KERG-a3

KERG-a1

Ant-b1

Ant-b2

$\mathrm{KGl}-\mathrm{c} 1$

$99 \mathrm{KGl}-\mathrm{c} 2$

$99 \mathrm{KGl}-\mathrm{C2}$

$0.97 \begin{aligned} & \mathrm{KGl}-\mathrm{c} 3 \\ & \mathrm{KGl}-\mathrm{c} 4\end{aligned}$

$\mathrm{KGl}-\mathrm{c} 4$
$\mathrm{KGl}-\mathrm{c5}$

KGI-c6

KERG-a4

KERG-a2

Arctic-a1

Arctic-a1
Arctic-b1

Arctic-c4

Arctic-c1

Arctic-c7

KERG-b

KERG-b
Arctic-c12

Arctic-c11

Arctic-c10

Eurythenes gryllus

0.76

Arctic-c9

Arctic-c8

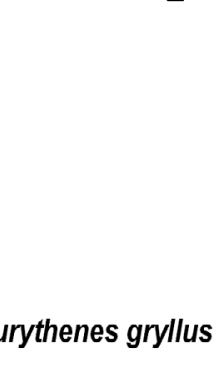

0.83

SAM-1

WDL-d1

0.5

Figure 2. Bayesian tree inferred for the second COI data-set including previously described species (d'Udekem d'Acoz and Havermans 2015), the newly obtained sequences in this study and the COI sequences from Ritchie, Jamieson, and Piertney (2015). Posterior probabilities above 0.50 are shown. 


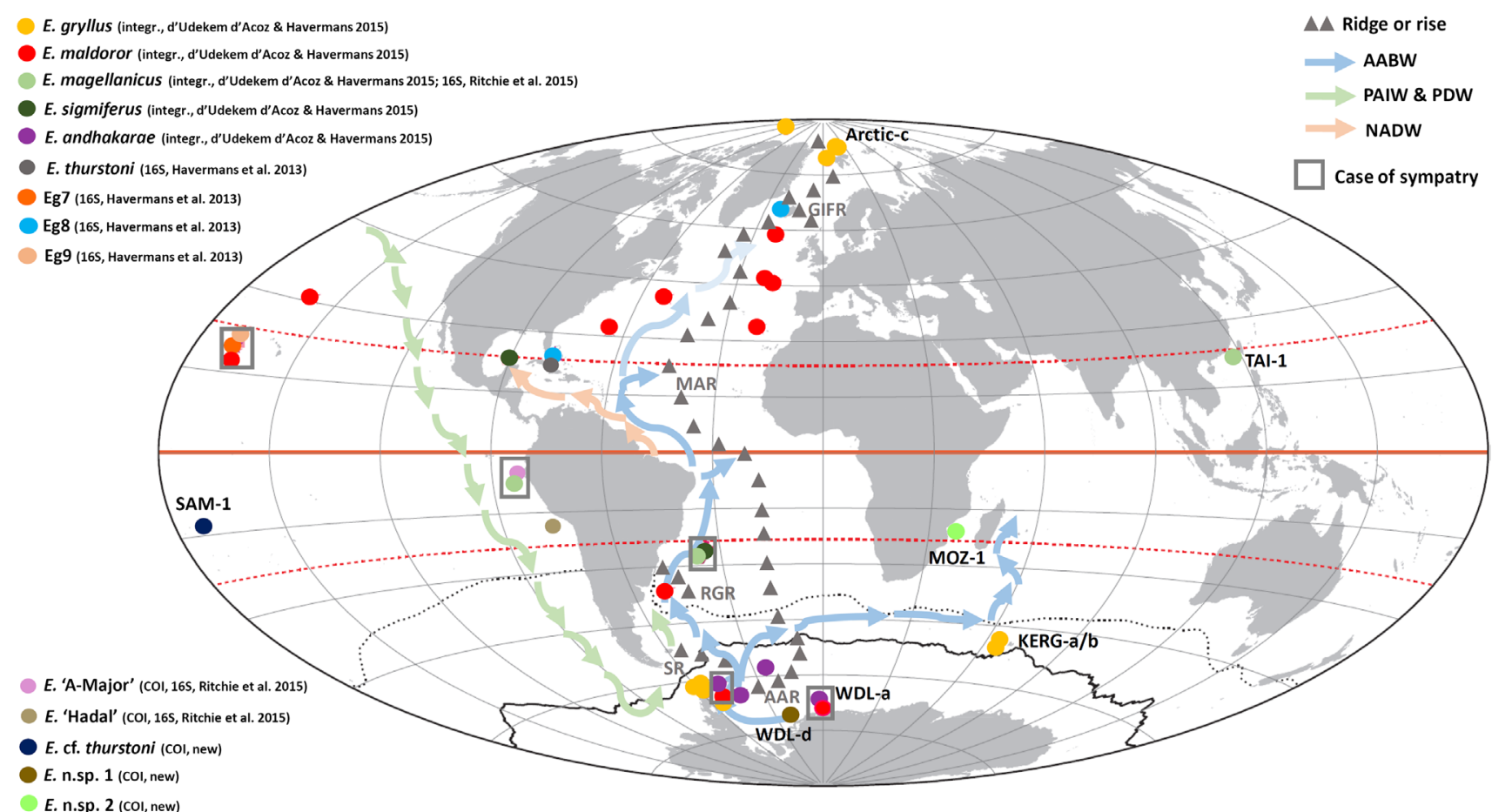

Figure 3. Geographic distributional ranges of the different Eurythenes species that have so far been confirmed with molecular or integrative (morphology and genes) methods. All described species or molecular species-level lineages of Eurythenes, excluding the pelagic species E. obesus, are represented here by different colours. Data include sequences from specimens obtained from France and Kocher (1996a), Escobar-Briones, Nájera-Hillman, and Alvarez (2010), Havermans et al. (2013), Ritchie, Jamieson, and Piertney (2015) and d'Udekem d'Acoz and Havermans (2015). Topographic and hydrographical features, hypothesised to limit or enhance dispersal, respectively, of the different species are indicated. The abbreviations of the new sampling sites for this study are added (e.g. Arctic-c). Localities where species have been found to occur in geographic and bathymetric sympatry (i.e. recovered in the same trap) are highlighted with a rectangle. Abbreviations: AABW - Antarctic Bottom Water, AAR - American Antarctic Ridge, GIFR- Greenland-Iceland-Faeroe Ridge, MAR - Mid-Atlantic Ridge, NADW - North Atlantic Deep Water, PAIW - Pacific Arctic Intermediate Water, PDW - Pacific Deep Water, RGR - Rio Grande Rise, SR - Scotia Ridge.

eastern Weddell Sea (WDL-a) and off the Antarctic Peninsula.

Nevertheless, wherever species are co-occurring geographically they are often separated on the bathymetric scale (Figure 4). There are examples at the scale of the ocean basin: the North Atlantic comprises three different species with $E$. maldoror only found at abyssal depths whilst $E$. thurstoni and Eg8 occur at bathyal depths, the Southern Ocean contains four species, with E. sp. 1 (WDL-d) and $E$. gryllus only found above $3000 \mathrm{~m}$ whilst E. maldoror and $E$. andhakarae have only been sampled below $3000 \mathrm{~m}$. This is also true at the more local scale: three species, Eurythenes maldoror as well as the two species-level lineages Eg7 and $\mathrm{Eg}$ 9, were recorded at four distinct depths (between ca. 3000 and $5000 \mathrm{~m}$ ) on the seamount Horizon Guyot in the North Pacific. However, in the South Atlantic three species occur, that were all sampled at abyssal depths: $E$. magellanicus, E. sigmiferus and E. maldoror.

So far the highest species richness was recorded in the Pacific with seven species-level lineages compared with five in the Atlantic, four in the Southern Ocean and only one in the Arctic, however, this picture is certainly biased due to an uneven sampling effort. As an example, this is the first time material from the Indian Ocean was included and the single specimen investigated represented a distinct species-level lineage. However, sampling effort in the Arctic was high compared to elsewhere, although limited to bathyal depths, but only one species was found so far. The newly uncovered species-level lineages $E$. n. sp. 1 and $E$. n. sp. 2 were sampled at bathyal depths and hence, the species richness of Eurythenes is now equal between abyssal and bathyal depths with seven species recorded for each zone (not considering the midwater species E. obesus) (Figure 4). This alters the earlier view of a comparatively lower (species) diversity at bathyal compared with abyssal depths (Havermans et al. 2013). Nevertheless, 'true' species richness between different regions or depths will only be comparable with a higher and non-biased sampling effort, both at a geographic and bathymetric scale. 


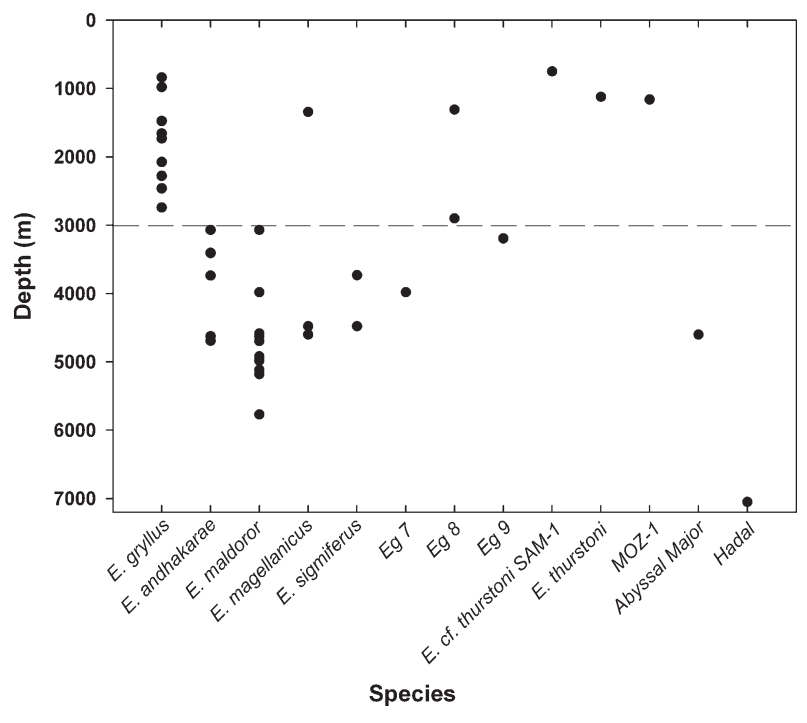

Figure 4. Depth distributions of the different Eurythenes species, except $E$. obesus, which is an entirely pelagic species. All records plotted here have been confirmed with molecular or integrative (morphology and genes) methods. Data included specimens investigated by France and Kocher (1996a), Escobar-Briones, Nájera-Hillman, and Alvarez (2010), Havermans et al. (2013), Ritchie, Jamieson, and Piertney (2015) and d'Udekem d'Acoz and Havermans (2015).

\section{Horizontal and vertical segregation: identifying true barriers}

\section{Topographic and hydrographical features}

It is known that topography can play a role as barriers for dispersal, reflected by a high genetic differentiation observed between populations situated at each side of an undersea mountain ridge. For example, the Mid-Atlantic Ridge, one of the largest and most distinctive topographic features in the deep sea, can restrict transoceanic gene flow for strictly abyssal organisms, which has been shown e.g. for molluscs (Etter et al. 2011). However, the distribution of Eurythenes species does not seem to be restricted by geological features, since several species have distributions encompassing mountain ridges or rises, indicating that recent or ongoing gene flow has occurred, if not on ecological, then at least on evolutionary timescales. This is the case for the abyssal species E. maldoror, distributed on each side of the Mid-Atlantic Ridge (MAR), which shows that at some point, there has been dispersal over the ridge at less elevated, bathyal, depths or across deep-water corridors (Figure 3). The Greenland-Iceland-Faeroe Ridge (GIFR) extends across the Atlantic in an east-west direction, separating the deep water basins of the Arctic Ocean and the northernmost Atlantic Ocean. The average sill depth ranges only from 480 to $600 \mathrm{~m}$ (Brix and Svavarsson 2010). Hence, the bathyal amphitropical species E. gryllus must be capable of, at least, carrying out jump-dispersal across this ridge. The same is true for the American Antarctic Ridge (AAR) and the Scotia Ridge (SR), which do not limit the distributions of the species $E$. andhakarae and E. maldoror, and the species E. maldoror and E. gryllus, respectively (Figure 3 ). Distinct species are present at each side of the Rio Grande Rise (RGR), which only allows a restricted exchange of abyssal waters (AABW) through the Vema and Hunter channels (Zenk et al. 1999). Indeed, E. maldoror was sampled in the Argentine Basin whilst E. sigmiferus and E. magellanicus occurred in the Brazil Basin, however, on a larger scale, this feature did not seem an obstacle for dispersal and gene flow since E. maldoror was also sampled in the North Atlantic.

Hydrographical features such as the Antarctic Bottom Water, the North Atlantic Deep Water, the Pacific Arctic Intermediate Water and the Pacific Deep Water (Figure 3 ) were proposed as conduits for dispersal (Havermans 2012; Havermans et al. 2013). COI haplotypes were shared between the Antarctic Peninsula and Weddell Sea both for E. andhakarae and E. maldoror, whereas for E. maldoror, the most abundant haplotype was shared between localities as far apart as the Argentine abyssal Basin and the eastern Weddell Sea. This could indicate that dispersal events are common within the Southern Ocean and between the Southern Ocean and the South Atlantic at abyssal depths. Hence, it was previously hypothesised that dispersal between these regions could be facilitated by the presence of the Antarctic Bottom Water, formed in the Weddell Sea and of which the main pathway flows via the Argentine abyssal Basin (Murray and Reason 1999). Another hypothesis implies that the connectivity between the North Pacific, the Southern and southwest Atlantic (for E. maldoror and E. magellanicus, Figure 3) is facilitated by southward spreading of the Pacific Arctic Intermediate Water and mixing with the Pacific Deep Water (PDW) that crosses the equator and moves further south along South America. Ultimately, this water mass mixes with the Circumpolar Deep Water and passes the Drake Passage to the Southwest Atlantic (Arkhipkin, Laptikhovsky, and Brickle 2010). For E. sigmiferus, the connectivity between the Brazil Basin and the Gulf of Mexico, at abyssal depths, may be facilitated by the North Atlantic Deep Water (NADW, only partly illustrated on Figure 3) through the western South Atlantic, by deep passages permitting the inflow of NADW into the Venezuelan and Columbian basins and further through the Yucatán Channel into the Gulf of Mexico (Fratantoni et al. 1997; Sheinbaum et al. 2002).

Whether these species are linked to particular water masses cannot be ruled out, however, for a strong swimmer such as Eurythenes, passive dispersal with currents is no longer tenable. Drifting with currents may be a valuable hypothesis for less mobile amphipods that display 
swimming behaviour towards the surface which enables them to disperse with the strong surface currents (e.g. epibenthic amphipods in the North Sea, Havermans et al. 2007). However, scavenger species such as Eurythenes are not only able to easily swim against currents (Laver et al. 1985) but are also supposed to do so in order to detect chemical signatures of food falls (Premke et al. 2003). Scavenger amphipods passively drifting with water currents above the seafloor, just like vultures hovering with air currents (Ruxton and Houston 2004), may not be a suitable analogy when bearing in mind the sluggish currents typical for the deep sea (e.g. Schmitz and McCartney 1993) and the unlikelihood to detect food falls in the surroundings when swimming with the current.

It becomes clear from these findings regarding Eurythenes species' distributions but also from logical reasoning that hydrographical and topographic features are not influencing dispersal of this and other lysianassoid amphipods to such an extent that they represent true barriers or conduits. Cosmopolitan or widespread distributions have yet been confirmed with molecular methods in a vast array of deep-sea organisms. The vent-associated tubeworm Sclerolinum contortum was shown to be cosmopolitan, characterised by a genetic homogeneity between the two poles and in the Gulf of Mexico (Georgieva et al. 2015) and the genetically investigated coral species Paragorgia arborea was observed to have a distribution that spans several oceanic basins (Herrera, Shank, and Sánchez 2012). However, these species can accomplish longer distance dispersal via larval propagules, whilst peracarid crustaceans do not have larval stages. Nonetheless, an undersea ridge did not represent a barrier for a small non-dispersive isopod species (Brix, Svavarsson, and Leese 2014). Smaller lysianassoid amphipod species also showed a genetic connectivity between the Southern Ocean, the South and North Atlantic (Havermans 2014). Thus, the large and mobile Eurythenes species should definitely be capable of dispersing across ridges, they are not restricted to particular water masses characterised by certain temperatures and do not rely on drifting with large current systems to accomplish wide-ranging dispersal, hence, other yet unknown factors should be responsible for the restricted distributions observed for some species and the widespread occurrences observed in others.

\section{The genetic break at 3000 m: a persistent sampling artefact?}

The genetic break observed around $3000 \mathrm{~m}$ is still apparent for all species but one (Figure 4). Indeed, the specimen sampled off Taiwan at a bathyal depth of around $1300 \mathrm{~m}$ clustered within the abyssal clade representing E. magellanicus, and hence this is the first species - corroborated with molecular data - that has been reported from both below and above $3000 \mathrm{~m}$. Previously, this limit was interpreted as an ubiquitous barophysical tolerance boundary (Rex and Etter 2010) - below which selection would have induced enzymatic adaptations - observed throughout all oceans for Eurythenes and for other organisms such as the bivalve Deminucula atacellana (Zardus et al. 2006) and Neilonella salicensis (Glazier and Etter 2014). However, the effect of pressure on chemical reactions is not as straightforward and predictable as that of temperature, affecting some whilst not others; it is believed to be the most pronounced on the permeability of membranes and enzyme stability (Hochachka 1971). The latter is true particularly for enzymes that are involved in energy-yielding reactions (e.g. (per)oxidases, hydrogenases) opposite to hydrolytic enzymes (e.g. amylase) that are pressure-tolerant (Kim and Zobell 1972). Furthermore, enzymatic sensitivity to hydrostatic pressure is in many cases temperature dependent, and since distinct temperatures might be encountered across the different oceanic basins, this break at $3000 \mathrm{~m}$ seems to be rather a sampling artefact than an effect from hydrostatic pressure as a selective factor. George (1979) collected what is likely to be E. gryllus s.s. from the central Arctic basin at a depth of ca. $1800 \mathrm{~m}$ and maintained the specimens alive for three months in an aquarium. Their metabolism, measured by respiration rate and pleopod activity, did not vary whilst exposed experimentally to the in situ and in vitro pressures. Data on abyssal Eurythenes specimens are not available, however, in the case of the lysianassoid Paralicella caperesca, abrupt decompression after recovery at almost $6000 \mathrm{~m}$ only temporarily inactivated locomotion which was reversible, suggesting that vertical migrations of $3000 \mathrm{~m}$ are physiologically possible (Yayanos 1981). Moreover, Eurythenes species can easily cope with hydrostatic pressure gradients (Yayanos 1978); distinct life stages occupy different depths above the seafloor (e.g. Eustace et al. 2016) and individuals have also been reported from the sea surface (Templeman 1967). How bathymetric segregation can be maintained for a vertically migrating species remains a question to be further explored. Various other variables than hydrostatic pressure itself, embedded within the 'factor depth' are more likely to play a significant role in promoting population differentiation and eventually speciation, as outlined in Brix, Svavarsson, and Leese (2014). These environmental factors that vary across wide depth ranges include temperature, dissolved oxygen concentration, nutrient flux, topographic complexity and sediment characteristics (reviewed in Gage and Tyler 1991). The synergistic effect of temperature and hydrostatic pressure seems to be an important factor determining the physiological limits and hence the distributional range of a species, which has been shown for the lysianassoid bathyal amphipod Stephonyx biscayensis (Brown and Thatje 2011). Thus, selection 
might have favoured different enzymes tuned to particular a combination of temperature and pressure gradients.

\section{A patchwork of rare but widespread species}

These and previous results corroborate the 'patchwork theory' on deep-sea brooding crustaceans, stating that these are often composed of several distinct species occurring in sympatry (Raupach et al. 2007). Several Eurythenes species were characterised by a widespread, presumably cosmopolitan, distribution, whilst others seemed to be restricted to single ocean basins or topographic features (e.g. trench, seamount), with partly overlapping horizontal and vertical distributions and in some cases, a segregation along distinct depth ranges. The same mixture of overlapping horizontal and vertical species' distributions, of which some are widespread and others restricted, was observed within the gastropod genus Scaphander (Eilertsen and Malaquias 2015). Such findings highlight the need for processing a high number of specimens per locality, since several species-level lineages often occur in the same sample but in different proportions. As an example, of all specimens sampled in the Brazil Abyssal Basin, only one specimen belonged to E. sigmiferus, the remaining (around twenty) were E. magellanicus. Results also demonstrate that these locally less abundant species are not necessarily endemic but can be widely distributed, which seems to be the case for E. sigmiferus, supporting the theory that local rarity does not always equal a small geographic range (McClain and Hardy 2010; Rex 2002). After investigating a small number of additional samples, the diversity within $E$. gryllus sensu lato continues to increase, clearly suggesting that only a fraction of the species has yet been discovered. Morphological investigations also pointed out the presence of a distinct species in the Atacama Trench (Thurston, Petrillo, and Della Croce 2002) and Bowman and Manning (1972) also report morphological variations for specimens collected in the bathyal Caribbean. Finally, a higher (molecular) sampling effort is also needed to confirm whether some of the uncovered Eurythenes species are truly confined to a certain region or depth range or are actually more widespread.

\section{Ecological differentiation as a trigger for diversification}

It is believed that, particularly for the abyssal plains, few obvious barriers exist in the deep sea that would impede dispersal of organisms and this is even more the case for the mobile Eurythenes. The abyss is characterised as a uniform, homogeneous environment with few variable abiotic factors that could allow population differentiation and new species to form (e.g. Etter and Grassle 1992). However, in this argumentation, the variability of biotic factors, and their role in speciation and diversification, is often neglected since little is known about biotic interactions and the variability of food supply at local and regional scales in the deep ocean. It has been stated before that selection pressures may not differ over large distances in the deep sea (e.g. Bucklin, Wilson, and Smith 1987), however, in the case of scavenging amphipods, biotic factors such as food supply, in the shape of animal carcasses sinking down to the seafloor, and predation pressure, might vary across the different ocean basins and even at much more localised scales. The different Eurythenes species, and in particular those occurring in bathymetric and geographic sympatry, might occupy distinct ecological niches, being specialised on particular types of food falls or by displaying a distinct feeding behaviour, e.g. scavenging complemented by predation on organisms in the water column or feeding on detritus on the seafloor. DNA analyses of the gut content of abyssal specimens of E. gryllus showed a diverse diet composed of some invertebrates unlikely to be fed upon as carrion, suggesting predation as a feeding mode (Blankenship and Yayanos 2005). Moreover, using molecular and stable isotope analyses, hadal Eurythenes specimens were shown to use other sources of nutrition than large carrion alone, e.g. predation and feeding on detritus (Blankenship and Levin 2007). Some information on the specimens investigated here can be deduced from the sampling methods: one specimen of E. gryllus, from the Kerguelen Islands was caught with a trawl and was found clinging onto a Patagonian toothfish (Dissostichus), and the species found in the Mozambique Channel was sampled with a midwater trawl, possibly indicating feeding by predation or on immobilised or dead fish in the trawls, near the surface. In areas of high productivity, Eurythenes species could display a more preferential or specialised feeding on a particular type of food falls, such as whale (Smith and Baco 2003) or large fish falls (Higgs et al. 2014). Particular deepsea habitats that are often characterised by a higher food supply, such as trenches, canyons or seamounts, might have favoured species diversification, which could explain the co-occurrence of several distinct species-level lineages of Eurythenes on a single seamount (Horizon Guyot) or in a single trench (the Peru-Chile Trench).

\section{Conclusions}

It has to be noted that assumptions on taxon diversity and distribution drastically change when increasing sampling in the deep sea but are of crucial importance for impact studies in the context of planned deep-sea exploitation activities. The systematic processing of all samples with cost-effective molecular tools will help to unravel the patterns and vulnerability of the extremely diverse, patchy 
and underexplored fauna that the deep sea harbours. Future studies combining fast and slowly evolving genetic markers will allow us to test dispersal on ecological and evolutionary timescales and help to interpret the current distributional patterns. Nevertheless, getting a better picture of a species' ecology is of paramount importance for grasping how the organisms partition their environment and their feeding resources and hence, for understanding what is key in promoting allo- or sympatric speciation events in the deep ocean.

\section{Acknowledgements}

Molecular work was funded by an Antarctic Science Bursary (2012). This paper is contribution no. 11 to the vERSO project and the author was funded by the Belgian Science Policy Office (contract $\mathrm{n}^{\circ} \mathrm{BR} / 132 / \mathrm{A} 1 / \mathrm{vERSO}$ ). I thank Dr Cédric d'Udekem d'Acoz of the Royal Belgian Institute of Natural Sciences for morphological identifications and fruitful discussions. The anonymous reviewers are acknowledged for the valuable comments and remarks. I acknowledge chief scientist Dr A. Intes and IFREMER for the sampling during the SAMOA-I cruise with the RV Coriolis, the AWI and chief scientists, crew and scientists on board for trap sampling during the EASIZ II and ANDEEP III (ANT XXII/3) expedition with RV Polarstern, Dr Jørgen Berge and the crew of RV Jan Mayen for specimen collection in Svalbard. The MAINBAZA cruise with PI Dr Bouchet was operated by the Muséum national d'Histoire naturelle (MNHN) and Instituto Español de Oceanografica, as part of a cluster of Mozambique-Madagascar expeditions funded by the Total Foundation, Prince Albert II de Monaco Foundation, and Stavros Niarchos Foundation. These samples were kindly provided in loan by Dr Laure Corbari from the MNHN. Samples from Kerguelen, collected by the 'programme d'observation des pêcheries australes' under direction of Dr Guy Duhamel, were kindly provided by Dr Eléaume and Dr Chazeau (MNHN, Service des pêches des TAAF). I thank Dr Tin-Yan Chan from the Institute of Marine Biology, National Taiwan Ocean University in Keelung, Taiwan for providing me with specimens. This is ANDEEP publication 213 and CAML publication number 57.

\section{Disclosure statement}

No potential conflict of interest was reported by the author.

\section{Funding}

This work was supported by Antarctic Science Bursary (2012); Belgian Science Policy Office [contract nºR/132/A1/vERSO].

\section{References}

Arkhipkin, A. I., V. V. Laptikhovsky, and P. Brickle. 2010. "An Antipodal Link between the North Pacific and South Atlantic Oceans?" Deep Sea Research Part I: Oceanographic Research Papers 57 (8): 1009-1011. doi:http://dx.doi. org/10.1016/j.dsr.2010.05.004.
Baldwin, R. J., and K. L. Jr Smith. 1987. “Temporal Variation in the Catch Rate, Length, Color, and Sex of the Necrophagus Amphipod, Eurythenes gryllus, from the Central and Eastern North Pacific." Deep Sea Research Part A. Oceanographic Research Papers 34 (3): 425-439. doi:http://dx.doi. org/10.1016/0198-0149(87)90146-4.

Blankenship, L. E., and L. A. Levin. 2007. "Extreme Food Webs: Foraging Strategies and Diets of Scavenging Amphipods from the Ocean's Deepest 5 Kilometers." Limnology and Oceanography 52 (4): 1685-1697. doi:http://dx.doi. org/10.4319/lo.2007.52.4.1685.

Blankenship, L. E., and A. A. Yayanos. 2005. "Universal Primers and PCR of Gut Contents to Study Marine Invertebrate Diets." Molecular Ecology 14 (3): 891-899. doi:http://dx.doi. org/10.1111/j.1365-294X.2005.02448.x.

Bowman, T. E., and R. B. Manning. 1972. "Two Arctic Bathyal Crustaceans: the Shrimp Bythocaris cryonesus New Species, and the Amphipod Eurythenes gryllus, with In Situ Photographs from Ice Island T-3." Crustaceana 23 (2): 187 201. doi:http://dx.doi.org/10.1163/156854072X00363.

Brix, S., and J. Svavarsson. 2010. "Distribution and Diversity of Desmosomatid and Nannoniscid Isopods (Crustacea) on the Greenland-Iceland-Faeroe Ridge." Polar Biology 33 (4): 515-530. doi:http://dx.doi.org/10.1007/s00300-009-0729-8.

Brix, S., J. Svavarsson, and F. Leese. 2014. "A Multi-Gene Analysis Reveals Multiple Highly Divergent Lineages of the Isopod Chelator insignis (Hansen, 1916) South of Iceland.' Polish Polar Research 35 (2): 225-241. doi:http://dx.doi. org/10.2478/popore-2014-0015.

Brown, A., and S. Thatje. 2011. "Respiratory response of the deep-sea amphipod Stephonyx biscayensis indicates bathymetric range limitation by temperature and hydrostatic pressure." PLoS ONE 6: e28562. doi:http:// dx.doi.org/10.1371/journal.pone.0028562.

Bucklin, A., R. R. Jr. Wilson, and K. L. Jr. Smith. 1987. “Genetic Differentiation of Seamount and Basin Populations of the Deep-Sea Amphipod Eurythenes gryllus." Deep Sea Research Part A. Oceanographic Research Papers 34 (11): 1795-1810. doi:http://dx.doi.org/10.1016/0198-0149(87)90054-9.

Charmasson, S. S., and D. P. Calmet. 1987. "Distribution of Scavenging Lysianassidae Amphipods Eurythenes gryllus in the Northeast Atlantic: Comparison with Studies Held in the Pacific." Deep Sea Research Part A. Oceanographic Research Papers 34 (9): 1509-1523. doi:http://dx.doi. org/10.1016/0198-0149(87)90106-3.

Chevreux, E. 1905. "Diagnoses d'amphipodes nouveaux provenant de l'expédition antarctique du Français" [Descriptions of New Amphipods Originating from the Antarctic Expedition of the "Français"]. Bulletin de la Société Zoologique de France 30: 159-165.

Clement, M., D. Posada, and K. A. Crandall. 2000. "TCS: a Computer Program to Estimate Gene Genealogies." Molecular Ecology 9: 1657-1659. doi:http://dx.doi. org/10.1046/j.1365-294x.2000.01020.x.

De Broyer, C., M. Rauschert, and Y. Scailteur. 1999. "Structural and Ecofunctional Biodiversity of the Benthic Amphipod Taxocenoses". In The expedition ANTARKTIS XV/3 (EASIZ II) of Polarstern in 1998, edited by Arntz W., and J. Gutt. J. Berichte zur Polar- und Meeresforschung 301: 163-174.

Eilertsen, M. H., and M. A. Malaquias. 2015. "Speciation in the Dark: Diversification and Biogeography of the DeepSea Gastropod genus Scaphander in the Atlantic Ocean." 
Journal of Biogeography 42 (5): 843-855. doi:http://dx.doi. org/10.1111/jbi.12471.

Escobar-Briones, E., E. Nájera-Hillman, and F. Alvarez. 2010. "Unique 16S rDNA Sequences of Eurythenes gryllus (Crustacea: Amphipoda: Lysianassidae) from the Gulf of Mexico Abyssal Plain.” Revista Mexicana de Biodiversidad 81: 177-185.

Etter, R. J., and F. Grassle. 1992. "Patterns of Species Diversity in the Deep Sea as a Function of Sediment Particle Size Diversity." Nature 360: 576-578.

Etter, R. J., E. E. Boyle, A. Glazier, R. M. Jennings, E. Dutra, and M. R. Chase. 2011. "Phylogeography of a Pan-Atlantic Abyssal Protobranch Bivalve: Implications for Evolution in the Deep Atlantic." Molecular Ecology 20 (4): 829-843. doi:http://dx.doi.org/10.1111/j.365-294X.2010.04978.x.

Eustace, R. M., H. Ritchie, N. M. Kilgallen, S. B. Piertney, and A. J. Jamieson. 2016. "Morphological Stratification of Abyssal and Hadal Eurythenes gryllus sensu lato (Amphipoda: Lysianassoidea) from the Peru-Chile Trench." Deep-Sea Research Part I: Oceanographic Research Papers 109: 91-98. doi:http://dx.doi.org/10.1016/j.dsr.2015.11.005.

Folmer, O., M. Black, R. Hoeh, R. Lutz, and R. Vrijenhoek. 1994. "DNA Primers for Amplification of Mitochondrial Cytochrome c Oxidase Subunit I from Diverse Metazoan Invertebrates." Molecular Marine Biology and Biotechnology 3 (5): 294-299.

France, S. C., and T. D. Kocher. 1996a. "Geographic and Bathymetric Patterns of Mitochondrial 16S rDNA Sequence Divergence among Deep-Sea Amphipods, Eurythenes gryllus." Marine Biology 126 (4): 633-643. doi:http://dx.doi. org/10.1007/BF00351330.

France, S. C., and T. D. Kocher. 1996b. "DNA Sequencing of Formalin-Fixed Crustaceans from Archival Research Collections." Molecular Marine Biology and Biotechnology 5 (4): 304-313.

Fratantoni, D. M., R. J. Zantopp, W. E. Johns, and J. L. Miller. 1997. "Updated Bathymetry of the AnegadaJungfern Passage Complex and Implications for Atlantic Inflow to the Abyssal Caribbean Sea." Journal of Marine Research 55 (5): 847-860. doi:http://dx.doi. org/10.1357/0022240973224148.

Gage, J. D., and P. A. Tyler. 1991. Deep-sea Biology: A Natural History of Organisms at the Deep-Sea Floor. Cambridge: Cambridge University Press.

George, R. Y. 1979. "Behavioral and Metabolic Adaptations of Polar and Deep-Sea Crustaceans: A Hypothesis concerning Physiological Basis for Evolution of Cold Adapted Crustaceans." Bulletin of the Biological Society of Washington 1979 (3): 283-296.

Georgieva, M. N., H. Wiklund, J. B. Bell, M. H. Eilertsen, R. A. Mills, C. T. S. Little, and A. G. Glover. 2015. "A Chemosynthetic Weed: the Tubeworm Sclerolinum contortum is a Bipolar, Cosmopolitan Species." BMC Evolutionary Biology 15: 280. doi:http://dx.doi.org/10.1186/ s12862-015-0559-y.

Glazier, A. E., and R. J. Etter. 2014. "Cryptic Speciation along a Bathymetric Gradient." Biological Journal of the Linnean Society 113 (4): 897-913. doi:http://dx.doi.org/10.1111/ bij. 12389.

Hargrave, B. T. 1985. "Feeding Rates of Abyssal Scavenging Amphipods (Eurythenes gryllus) Determined in situ by Time-Lapse Photography." Deep Sea Research Part A.
Oceanographic Research Papers 32 (4): 443-450. doi:http:// dx.doi.org/10.1016/0198-0149(85)90090-1.

Hargrave, B. T., G. A. Phillips, N. J. Prouse, and P. J. Cranford. 1995. "Rapid Digestion and Assimilation of Bait by the Deep-Sea Amphipod Eurythenes gryllus." Deep Sea Research Part I: Oceanographic Research Papers 42 (11-12): 19051921. doi:http://dx.doi.org/10.1016/0967-0637(95)00080-1.

Havermans, C. 2012. DNA Barcoding, Phylogeography and Phylogeny of the Lysianassoidea (Crustacea: Amphipoda) from the Southern Ocean and the World's Deep Seas $\mathrm{PhD}$ diss., Université Catholique de Louvain.

Havermans, C. 2014. "Phylogeographic Patterns of the Lysianassoidea (Crustacea: Peracarida: Amphipoda).” In Biogeographic Atlas of the Southern Ocean, edited by C. De Broyer, P. Koubbi, H. J. Griffiths, B. Raymond, C. d' Udekem d' Acoz et al., 441-447. Cambridge: Scientific Committee on Antarctic Research.

Havermans, C., C. De Broyer, J. Mallefet, and V. Zintzen. 2007. "Dispersal Mechanisms in Amphipods: a Case Study of Jassa herdmani (Crustacea, Amphipoda) in the North Sea." Marine Biology 153 (1): 83-89. doi:http://dx.doi. org/10.1007/s00227-007-0788-8.

Havermans, C., G. Sonet, C. d'Udekem d'Acoz, Z. T. Nagy, and P. Martin. 2013. "Genetic and Morphological Divergences in the Cosmopolitan Deep-Sea Amphipod Eurythenes gryllus Reveal a Diverse Abyss and a Bipolar Species." PLoS ONE 8 (9): e74218. doi:http://dx.doi.org/10.1371/journal. pone. 0074218 .

Herrera, S., T. M. Shank, and J. A. Sánchez. 2012. "Spatial and Temporal Patterns of Genetic Variation in the Widespread Antitropical Deep-Sea Coral Paragorgia arborea." Molecular Ecology 21 (24): 6053-6067. doi:http://dx.doi.org/10.1111/ mec. 12074.

Higgs, N. D., A. R. Gates, and D. O. B. Jones. 2014. "Fish Food in the Deep Sea: Revisiting the Role of Large Food Falls." PLoS ONE 9 (5): e96016. doi:http://dx.doi.org/10.1371/ journal.pone.0096016.

Hochachka, P. W. 1971. "Enzyme Mechanisms in Temperature and Pressure Adaptation of Off-Shore Benthic Organisms: The Basic Problem." American Zoologist 11 (3): 479-490. doi:http://dx.doi.org/10.1093/icb/11.3.425.

Ingram, C. L., and R. R. Hessler. 1983. "Distribution and Behavior of Scavenging Amphipods from the Central North Pacific." Deep Sea Research Part A. Oceanographic Research Papers 30 (7): 683-706. doi:http://dx.doi.org/10.1016/01980149(83)90017-1.

Kim, J., and C. E. Zobell. 1972. "Agarase, Amylase, Cellulase and Chitinase Activity at Deep-Sea Pressures." Journal of the Oceanographical Society of Japan 28: 131-137. doi:http:// dx.doi.org/10.1007/BF02108756.

Kimura, M.1980. "A Simple Method for Estimating Evolutionary Rates of Base Substitutions through Comparative Studies of Nucleotide Sequences." Journal of Molecular Evolution 16 (2): 111-120. doi:http://dx.doi.org/10.1007/BF01731581.

Laver, M. B., M. S. Olsson, J. L. Endelman, and K. L. Smith. 1985. "Swimming Rates of Scavenging Deep-Sea Amphipods Recorded with a Free-Vehicle Video Camera." Deep Sea Research Part A. Oceanographic Research Papers 32 (9): 11351142. doi:http://dx.doi.org/10.1016/0198-0149(85)90067-6.

Markmann, M., and D. Tautz. 2005. "Reverse Taxonomy: an Approach towards Determining the Diversity of Meiobenthic Organisms based on Ribosomal RNA Signature Sequences." 
Philosophical Transaction of the Royal Society B: Biological Sciences 360: 1917-1924. doi:http://dx.doi.org/10.1098/ rstb.2005.1723.

McClain, C. R., and S. M. Hardy. 2010. "The Dynamics of Biogeographic Ranges in the Deep Sea." Proceedings of the Royal Society of London, Series B Biological Sciences 277: 3533-3546. doi:http://dx.doi.org/10.1098/rspb.2010.1057.

Milne Edwards, H. 1848. "Sur un crustacé amphipode, remarquable par sa grande taille" [On an Amphipod Crustacean, Characterized by its Large Size]. Annales des Sciences Naturelles 3 (9): 398.

Murray, R. J., and C. J. C. Reason. 1999. "Influences of Topography on the Modeling of Abyssal Water Masses. Part I: Effects of Channel Representation." Journal of Physical Oceanography 29: 2851-2871. doi:http://dx.doi. org/10.1175/1520-0485(1999)029<2851:IOTOTM>2.0. $\mathrm{CO} ; 2$.

Posada, D. 2008. "JModelTest: Phylogenetic Model Averaging." Molecular Biology and Evolution 25: 1253-1256. doi:http:// dx.doi.org/10.1093/molbev/msn083.

Premke, K., and M. Graeve. 2009. "Metabolism and Physiological Traits of the Deep Sea Amphipod Eurythenes gryllus." Vie et Milieu - Life and Environment 59 (3-4): 251-260.

Premke, K., S. Muyakshin, M. Klages, and J. Wegner. 2003. "Evidence for Long-Range Chemoreceptive Tracking of Food Odour in deep-sea scavengers by scanning sonar data." Journal of Experimental Marine Biology and Ecology 285-286: 283-294. doi:http://dx.doi.org/10.1016/S00220981(02)00533-6.

Raupach, M. J., M. Malyutina, A. Brandt, and J.-W. Wägele. 2007. "Molecular Data Reveal a Highly Diverse Species Flock within the Munnopsoid Deep-Sea Isopod Betamorpha fusiformis (Barnard, 1920) (Crustacea: Isopoda: Asellota) in the Southern Ocean." Deep-Sea Research Part II: Topical Studies in Oceanography 54 (16-17): 1820-1830. doi:http:// dx.doi.org/10.1016/j.dsr2.2007.07.009.

Rex, M. A. 2002. "Biogeography of the Deep-Sea Gastropod Palazzia planorbis (Dall, 1927): An Uncommon Form of Rarity." Nautilus 116: 36-38.

Rex, M. A., and R. J. Etter. 2010. Deep-sea Biodiversity: Pattern and Scale. Cambridge, MA: Harvard University Press.

Ritchie, H., A. J. Jamieson, and S. B. Piertney. 2015. "Phylogenetic Relationships among Hadal Amphipods of the Superfamily Lysianassoidea: Implications for Taxonomy and Biogeography." Deep Sea Research Part I: Oceanographic Research Papers 105: 119-131. doi:http:// dx.doi.org/10.1016/j.dsr.2015.08.014.

Ronquist, F., and J. P. Huelsenbeck. 2003. "MrBayes 3: Bayesian Phylogenetic Inference under Mixed Models." Bioinformatics 19: 1572-1574. doi:http://dx.doi.org/10.1093/ bioinformatics/btg180.

Ruxton, G. D., and D. C. Houston. 2004. "Energetic Feasibility of an Obligate Marine Scavenger." Marine Ecology Progress Series 266: 59-63.

Schmitz Jr, W. J., and M. S. McCartney. 1993. "On the North Atlantic Circulation." Reviews in Geophysics 31: 29-39. doi:http://dx.doi.org/10.1029/92RG02583.

Schwarz, G. 1978. "Estimating the Dimension of a Model." The Annals of Statistics 6: 461-464.

Sheinbaum, J., J. Candela, A. Badan, and J.Ochoa. 2002. "Flow Structure and Transport in the Yucatán Channel." Geophysical Research Letters 29 (3): 10-1-10-4. doi:http:// dx.doi.org/10.1029/2001GL013990.
Smith, C. R., and A. R. Baco. 2003. "Ecology of Whale Falls at the Deep-Sea Floor." Oceanography and Marine Biology: An Annual Review 41: 311-354.

Smith, K. L. Jr., G. A. White, M. B. Laver, R. R. McConnaughey, and J.P. Meador. 1979. "Free Vehicle Capture of Abyssopelagic Animals." Deep Sea Research Part A. Oceanographic Research Papers 26 (1): 57-64. doi:http://dx.doi.org/10.1016/01980149(79)90085-2.

Stoddart, H., and J. Lowry. 2004. “The Deep-sea Lysianassoid Genus Eurythenes (Crustacea, Amphipoda, Eurytheneidae n. fam.)." Zoosystema 26: 425-468.

Tamura, K., G. Stecher, D. Peterson, A. Filipski, and S. Kumar. 2013. "MEGA6: Molecular Evolutionary Genetics Analysis Version 6.0." Molecular Biology and Evolution 30 (12): 2725 2729. doi:http://dx.doi.org/10.1093/molbev/mst197.

Templeman, W. 1967. "Predation on Living Fishes on Longline in Baffin Bay by the Amphipod Eurythenes gryllus (Lichtenstein) and a New Distribution Record." Journal of the Fisheries Research Board of Canada 24 (1): 215-217. doi:http://dx.doi.org/10.1139/f67-020.

Thoen, H. H., G. Johnsen, and J. Berge. 2011. "Pigmentation and Spectral Absorbance in the Deep-Sea Arctic Amphipods Eurythenes gryllus and Anonyx sp." Polar Biology 34 (1): 8393. doi:http://dx.doi.org/10.1007/s00300-010-0861-5.

Thurston, M. H., and B. J. Bett. 1995. "Hatchling Size and Aspects of Biology in the Deep-Sea Amphipod Genus Eurythenes (Crustacea: Amphipoda)." Internationale Revue der gesamten Hydrobiologie und Hydrographie 80 (2): $201-$ 216. doi:http://dx.doi.org/10.1002/iroh.19950800209.

Thurston, M. H., M. Petrillo, and N. Della Croce. 2002. "Population Structure of the Necrophagous Amphipod Eurythenes gryllus (Amphipoda: Gammaridea) from the Atacama Trench (South-East Pacific Ocean)." Journal of the Marine Biology Association of the United Kingdom 82 (2): 205 211. doi:http://dx.doi.org/10.1017/S0025315402005374.

d'Udekem d'Acoz C., and C. Havermans. 2015. "Contribution to the Systematics of the Genus Eurythenes S.I. Smith in Scudder, 1882 (Crustacea: Amphipoda: Lysianassoidea: Eurytheneidae)." Zootaxa 3971 (1): 1-80. doi:http://dx.doi. org/10.11646/zootaxa.3971.1.1.

Yayanos, A. A. 1978. "Recovery and Maintenance of Live Amphipods at a Pressure of 580 Bars from an Ocean Depth of 5700 m." Science 200: 1056-1059. doi:http://dx.doi. org/10.1126/science.200.4345.1056.

Yayanos, A. A. 1981. "Reversible inactivation of deep-sea amphipods (Paralicella capresca) by a decompression from 610 bars to atmospheric pressure." Comparative Biochemistry and Physiology 69 (A): 563-565.

Zardus, J. D., R. J. Etter, M. R. Chase, M. A. Rex, and E. E. Boyle. 2006. "Bathymetric and Geographic Population Structure in the Pan-Atlantic Deep-Sea Bivalve Deminucula atacellana (Schenck, 1939)." Molecular Ecology 15 (3): 639-651. doi:http://dx.doi.org/10.1111/ j.1365-294X.2005.02832.x.

Zenk, W., G. Siedler, B. B. Lenz, and N. G., Hogg. 1999. "Antarctic Bottom Water Flow through the Hunter Channel." Journal of Physical Oceanography 29 (11): 2785-2801. doi:http:// dx.doi.org/10.1175/1520-0485(1999)029<2785:ABWFTT> 2.0.CO;2.

Zuccon, A., and D. Zuccon. 2014. "MrEnt: An Editor for Publication-Quality Phylogenetic Tree Illustrations." Molecular Ecology Resources 14 (5): 1090-1094. doi:http:// dx.doi.org/10.1111/1755-0998.12253. 